\title{
Can savanna burning projects deliver measurable greenhouse emissions reductions and sustainable livelihood opportunities in fire-prone settings?
}

\author{
Jeremy Russell-Smith • Catherine Monagle • Margaret Jacobsohn • \\ Robin L. Beatty • Bibiana Bilbao • Adriana Millán • Hebe Vessuri • \\ Isabelle Sánchez-Rose
}

Received: 29 January 2013 / Accepted: 27 August 2013 / Published online: 7 November 2013

(C) The Author(s) 2013. This article is published with open access at Springerlink.com

\begin{abstract}
Savannas constitute the most fire-prone vegetation type on earth and are a significant source of greenhouse gas emissions. Most savanna fires are lit by people for a variety of livelihood applications. 'Savanna burning' is an accountable activity under the Kyoto Protocol, but only Australia, as a developed economy, accounts for emissions from

This article is part of a Special Issue on "Climate Change Mitigation and Adaptation with Local Communities and Indigenous Peoples" edited by Kirsty Galloway McLean, Ameyali Ramos Castillo, Edwin Castellanos, and Aqqaluk Lynge.
\end{abstract}

Electronic supplementary material The online version of this article (doi:10.1007/s10584-013-0910-5) contains supplementary material, which is available to authorized users.

J. Russell-Smith $(\bowtie)$

North Australian Indigenous Land \& Sea Management Alliance, Darwin Centre for Bushfires Research, RIEL, Charles Darwin University, Darwin, Australia

e-mail: Jeremy.Russell-Smith@cdu.edu.au

C. Monagle

Traditional Knowledge Initiative, United Nations University - Institute of Advanced Studies, Darwin, Australia

M. Jacobsohn

One World Consulting, Swakopsmund, Namibia

R. L. Beatty

321Fire, Inhambane, Mozambique

B. Bilbao • A. Millán

Dpto. de Estudios Ambientales, Universidad Simón Bolívar, Caracas, Venezuela

H. Vessuri

Centro de Investigaciones en Geografía Ambiental, UNAM, Morelia Campus, Mexico

H. Vessuri

Centro de Estudios de Transformación Social (CETSCC), Instituto Venezolano de Investigaciones Científicas (IVIC), Caracas, Venezuela

I. Sánchez-Rose

Centro de Estudios del Desarrollo (CENDES), Universidad Central de Venezuela, Caracas 1040,

Venezuela 
this source in its national accounts. Over the past decade considerable effort has been given to developing savanna burning projects in northern Australia, combining customary indigenous (Aboriginal) approaches to landscape-scale fire management with development of scientifically robust emissions accounting methodologies. Formal acceptance by the Australian Government of that methodology, and its inclusion in Australia's developing emissions trading scheme, paves the way for Aboriginal people to commercially benefit from savanna burning projects. The paper first describes this Australian experience, and then explores options for implementing community-based savanna burning emissions reduction projects in other continental savanna settings, specifically in Namibia and Venezuela. These latter examples illustrate that savanna fire management approaches potentially have broader application for contributing to livelihood opportunities in other fire-prone savanna regions.

\section{Introduction}

Considerable interest currently surrounds the potential for developed countries to pay for environmental management services in developing nations in the context of greenhouse gas (GHG) emissions mitigation and associated activities. In tropical and sub-tropical regions such projects to date have focused especially on biodiverse, carbon-rich forested systems and related biodiversity, hydrological and livelihood co-benefits (e.g. Engel and Palmer 2008; de Koning et al. 2011). Relatively little attention has been given to the development of environmental services projects in other tropical biomes with globally significant mitigation issues, fire-prone savannas especially.

Savannas, defined broadly as tropical and sub-tropical grasslands with varying densities of tree cover, are the most fire-prone vegetation on earth. They support about $10 \%$ of the human population, occupy one-sixth of the land surface and, while rates of land use change are uncertain, are likely to suffer twice the rate of conversion as for tropical forests (White et al. 2000; Grace et al. 2006). By comparison with tropical forests, savannas store about $15 \%$ (vs. $25 \%$ ) of the total carbon contained in the world's vegetation and soil organic matter, and account for a similar proportion (c. $30 \%$ ) of terrestrial net primary productivity (Grace et al. 2006). The lower storage capacity of savannas is largely due to the effects of frequent fires returning carbon to the atmosphere. The burning of savanna is primarily undertaken by people for a variety of agricultural, pastoral, and customary management activities. Between 1997 and 2009 fires in savanna (incorporating grassland, open savanna and woodland) accounted for $60 \%$ of total global fire emissions; fires from grassland, open savanna and woodland also accounted annually for $36 \%$ of methane $\left(\mathrm{CH}_{4}\right)$ and $58 \%$ of nitrous oxide $\left(\mathrm{N}_{2} \mathrm{O}\right)$ emissions from fire sources globally. Recent studies estimate that around half of global fire carbon emissions come from Africa, with South America contributing between 15 and $27 \%$, and Australia < $10 \%$ (Schultz et al. 2008; van der Werf et al. 2010). Figures 1 and 2 below illustrate mean annual global fire carbon emissions and dominant fire types respectively.

In this paper we first address the development of formal methodological and regulatory frameworks, and practical experience and challenges associated with establishing, emissions abatement savanna fire management projects in Australia. We then explore the potential for implementing complementary projects in fire-prone African and South American settings, with particular reference to current experience in Namibia and Venezuela, respectively. Following from this country-specific discussion, we consider what is needed for savanna fire management to reach its full 


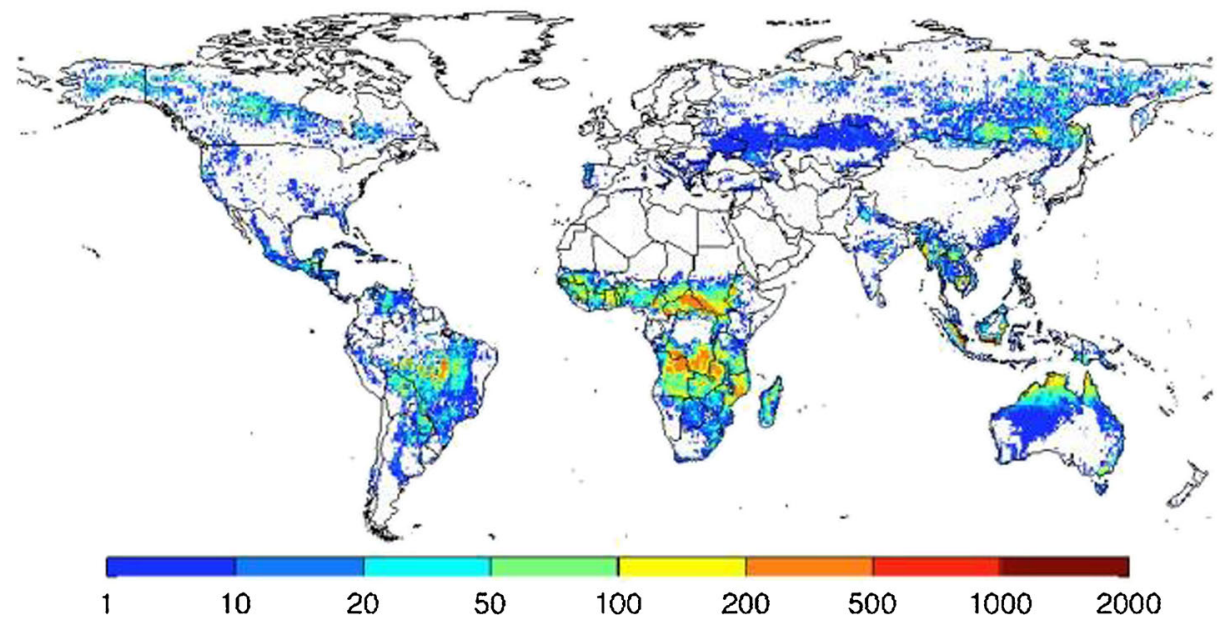

Fig. 1 Mean annual fire carbon emissions ( $\mathrm{g} \mathrm{Cm}-2$ year -1$)$, averaged over 1997-2009. This quantity is the product of the fuel consumption and the burned area within the grid cell, divided by the total area of the grid cell. From van der Werf et al. (2010)

potential for supporting sustainable livelihoods globally. In particular, we explore the potential livelihood benefits of an emissions abatement savanna fire management approach, and the many challenges that may be associated with implementation. We conclude by considering what is required to encourage broader acceptance of and investment in savanna fire management as a robust greenhouse gas emissions mitigation activity.

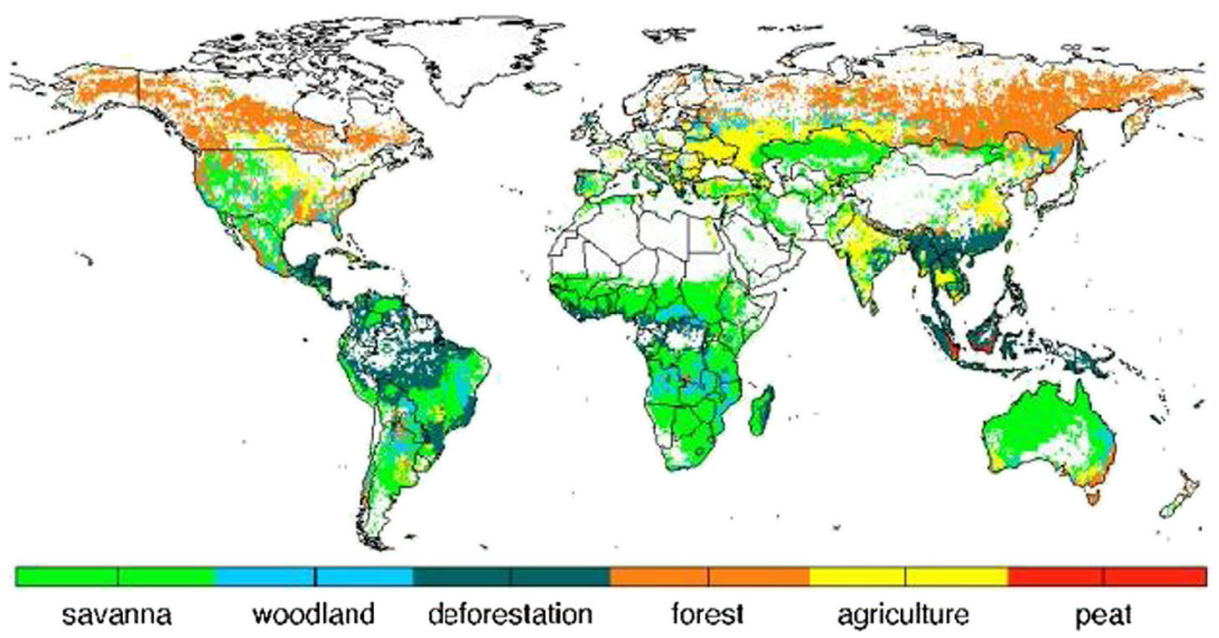

Fig. 2 Dominant fire type in each $0.5^{0}$ grid cell based on carbon emissions. Savanna fires include grassland fires; deforestation includes degradation. Woodland and savanna fires were separated based on the relative contributions from woody or herbaceous fuels to total emissions, respectively. From van der Werf et al. (2010) 


\section{Savanna burning in Australia}

\subsection{Australian conditions}

The savannas of northern Australia occupy $1.9 \mathrm{M} \mathrm{km}^{2}$ and occur mostly under markedly seasonal monsoonal rainfall conditions, generally receiving an average of $>500 \mathrm{~mm}$ rainfall p.a. (See Online Resource 1 for further details on Australian savannas.)

The sparse population, limited infrastructure, and low economic base, has resulted today in fire regimes in many regional settings being unmanaged and characterised by the frequent (annual-biennial) recurrence of large $\left(>1000 \mathrm{~km}^{2}\right)$ wildfires occurring predominantly late in the dry season. An average of $\sim 20 \%$ of Australia's savanna region is burnt each year (Russell-Smith et al. 2007), with fire frequencies exceeding $50 \%$ p.a. in extensive higher rainfall regions (Felderhof and Gillieson 2006; Russell-Smith et al. 2009b).

\subsection{National accounting and project-scale savanna burning}

Under the provisions of the Kyoto Protocol, Australia's National Greenhouse Gas Inventory (NGGI) accounts for greenhouse gas (GHG) emissions from savanna burning specifically for the long-lived chemical species, methane $\left(\mathrm{CH}_{4}\right)$ and nitrous oxide $\left(\mathrm{N}_{2} \mathrm{O}\right)$. In accord with international accounting rules, Australia's NGGI does not account for $\mathrm{CO}_{2}$ emissions from savanna burning on the assumption that $\mathrm{CO}_{2}$ emissions in one burning season are negated by vegetation growth in subsequent growing seasons (IPCC 1997).

An essential premise underlying Australia's recently developed savanna burning methodology (Russell-Smith et al. 2009a; DCCEE 2012; Meyer et al. 2012) is that reductions in fire frequency result in reduced GHG emissions because more of the fuel biomass (mostly grass and leaf litter) is decomposed biologically through pathways that, compared with savanna fires, produce lower relevant emissions per unit biomass consumed (Cook and Meyer 2009). In unburnt north Australian savannas, emissions of $\mathrm{CH}_{4}$ and $\mathrm{N}_{2} \mathrm{O}$ arising from biological decomposition pathways are likely to be less than $10 \%$ than that from fire (Cook and Meyer 2009; Jamali et al. 2011).

As allowed for under IPCC rules, Australia's NGGI accounts for GHG emissions from savanna burning using a methodology incorporating country-specific parameters and emission factors (ANGA 2011) (methodology details provided in Online Resource 1).

Recent impetus for the development of nationally accredited project-scale savanna burning accounting has come from the establishment of Australia's legislated agricultural carbon offsets program, the Carbon Farming Initiative. Accredited offsets generated under the CFI are formally recognised by the Australian Government for trading in voluntary and existing international regulatory markets, and the national regulatory scheme that took effect from 1 July 2012.

The approved savanna burning accounting methodology (DCCEE 2012) establishes strict accounting protocols prescribing all methodological and calculation procedures, vegetationfuel type and fire mapping requirements, and use of requisite parameter values, satellite imagery and acceptable data sources. Key components of that accounting methodology are that (a) registered project proponents have to provide evidence that they have legal access to manage the project area for savanna burning purposes - importantly, this does not equate to needing to own the land; (b) in each project year, carbon credits are generated against the preceding 10-year pre-project accountable emissions baseline, such that one credit is generated for each t. $\mathrm{CO}_{2}$-e abated with respect to that baseline; and (c) projects can be registered for 7 years. 


\subsection{Western Arnhem land experience (WALFA project)}

Much of the development of Australia's savanna burning program, including both operational and scientific aspects, has been derived from experience with the undertaking of the Western Arnhem Land Fire Abatement (WALFA) project that commenced in 1997. WALFA operates over $28,000 \mathrm{~km}^{2}$ of indigenous-owned land in rugged, very remote and fire-prone savanna in the 'Top End' of the Northern Territory. (see Online Resource 1 for more details on WALFA.)

From 2000, the WALFA scientific program incorporated development of a savanna burning GHG emissions accounting methodology, and associated recognition of the potential for strategic landscape fire management in the project area to reduce GHG emissions on an industrial scale. In 2005, a 17-year agreement was reached between WALFA landowners, the Northern Territory Government, and a transnational energy company, to annually offset 100,000 t. $\mathrm{CO}_{2}$-e from the Liquefied Natural Gas plant for a fee of AUS\$1.1 M p.a. (indexed to 2006). Over the period 2005-2011, effective fire management in the WALFA project area has delivered substantially in excess of its contracted commitment (Russell-Smith et al. 2013).

With the implementation of Australia's emissions trading scheme from in mid- 2012 (albeit with a fixed price during the first 3 years), considerable interest exists for expanding WALFAstyle savanna burning projects in other fire-prone regions of northern Australia. Much of that interest focuses on lands owned or managed by indigenous Australians. While it is our contention that, as illustrated by WALFA, it is eminently feasible to (a) operationally implement strategic fire management at landscape scales, and (b) apply robust and transparent GHG emissions accounting procedures, far more challenging are the multi-faceted, cross-cultural requirements for establishing effective and inclusive governance arrangements.

\section{Savanna burning in southern Africa}

\subsection{Background to savanna burning in southern Africa}

The savannas of southern Africa occupy c. $10 \mathrm{M} \mathrm{km}^{2}$ (43\% of the landmass) occurring under markedly seasonal rainfall conditions up to $1750 \mathrm{~mm}$ p.a. and extending into areas of lower and less seasonal rainfall than in Australia and South America due to higher soil fertility (Lehmann et al. 2011). (See Online Resource 1 for further details on African savannas.)

The use of fire to manage or access natural resources is prevalent for slash-and-burn agriculture, pasture management, forest product harvesting, pest control, hunting and honey collection. Communal land tenure with various types of traditional/customary authority structures comprises the vast majority of the 16 southern Africa nations ${ }^{1}$ south of the equator. Together with protected areas, including national parks and gazetted forests, they commonly occupy the infertile areas. Individualized leasehold or freehold land title is typical of fertile areas. Savanna burning is regulated, with a few exceptions, by prevention- and suppressionoriented fire management legislation and policies, maintained since colonial administrations revoked local burning practices and control (Frost 1998; FAO 2006). Typically, insufficient and inconsistent land and fire management legislation, administered by centralized governments with limited capacity, inadequately address the appropriate use of fire on communal lands. The absence of clearly defined processes, roles and responsibilities for decision-making, combined

\footnotetext{
${ }^{1}$ Angola, Botswana, Burundi, Democratic Republic of Congo, Lesotho, Madagascar, Malawi, Mozambique, Namibia, Republic of Congo, Rwanda, South Africa, Swaziland, Tanzania, Zambia and Zimbabwe.
} 
with weak local-level governance and community capacity, results in uncoordinated savanna burning through much of southern Africa.

\subsection{Potential for emissions abatement fire management projects in southern African savannas - an example from Namibia}

There is considerable potential to implement emissions abatement fire management projects comparable to the Australian initiative in southern African savannas. Suitable conditions for offset burning projects in fire-prone savanna settings to deliver emissions reductions and sustainable livelihood benefits are discussed using Namibia, with specific reference to a landscape-scale strategic fire management initiative in the Caprivi Region, as a characteristic example of the region.

Savannas cover c. $50 \%$ of Namibia with broad-leafed nutrient poor savannas, supporting a population of 5-10 persons $\mathrm{km}^{-2}$, occurring in the northeast regions. Customary rights to natural resources are well established in Namibia and community-based natural resource management (CBNRM) policy and legislation are well developed. National programs have established c. 100 legally recognized community-based structures of communal area conservancies and community forests (NACSO 2012). In Caprivi Region these provide employment and supplement livelihoods, through tourism and utilisation of forest products, for communities situated on communal lands in close proximity to protected areas. They also play a key role in sustainable wildlife and high value plant management of the region. Experience from an innovative integrated fire management program (Integrated Rural Development and Nature Conservation Caprivi Program) implemented between 2006 and 2010 in over $10,000 \mathrm{~km}^{2}$ provides valuable insights into the potential for a savanna burning offset program in this representative fire-prone setting.

In Caprivi, frequent uncontrolled high intensity late dry season fires negatively impact Caprivian community livelihoods through loss of life and property (houses, food stores and fences), and reducing the availability, productivity and long-term sustainability of natural resources leading to increased poverty (Kamminga 2001: FAO 2011). This scenario is important for potential savanna burning offset programs as reduction of area burnt annually and shift in burning seasonality to the early dry season, required for emissions abatement, is needed for providing sustainable livelihood benefits.

As in the Australian context, controlled burns in the Caprivi Program collectively reduce and fragment fuel load, creating a landscape of interlinked burnt and unburnt patches and corridors that minimize the occurrence and extent of late dry season fires. It is quite feasible to deliver emissions abatement based on this type of communal land use-oriented controlled fire management in these settings. Countries where frequent (annual/biennial) fires affect $>50 \%$ of the land area, including Angola, Zambia and Mozambique (Archibald et al. 2010), highlight the potential applicability of this scenario to extensive southern African savanna regions.

To enable savanna burning offset programs, legislation and policies must include provisions that permit the use of fire by communities under specific requirements and regulations. Alongside CBNRM policy and legislation, Namibia has provision in existing forestry legislation for Community-Based Forest Management (CBFiM) structures since 2001. Intended to empower communities by promoting involvement in fire management, it provides for the establishment of community committees and allows community members to participate actively in fire management planning and implementation. Despite this enabling legislation, minimal to no establishment of these structures has occurred due to insufficient government capacity. Regulation of community burning, consisting of prevention and suppression policies extension through education/awareness, firebreaks and wildfire suppression training, has typically been 
limited, haphazard and ineffective. Communities have been excluded from decision-making and the lighting of fires is illegal on communal land without authorization from the Directorate of Forestry.

The Caprivi Program capitalized on the CBFiM legislation to re-establish fire management rights, responsibilities and decision-making to communities, specifically to permit controlled burning on communal lands. Institutional structures in well-established Caprivi communal area conservancies and community forests provided straightforward and effective access to communities and traditional leadership. However, deeply entrenched fire prevention and suppression convictions, lack of skills and knowledge, inadequate local authority ownership, and skepticism in community ability, are issues that impeded institutionalization of the CBFiM approach into mainstream government policy and implementation.

The local social organization could be drawn upon to facilitate establishment of fire committees and programs with relatively easy and direct access to local knowledge and labour. As a manageable local-level 'fire management unit', these institutional structures are ideal for savanna burning offset programs. With numerous stakeholders and competing land uses, effective and sustainable CBFiM programs require a medium- to long-term development process. CBNRM income derived from tourism and forestry products are insufficient for these structures to independently fund fire management services for the community. Income generated from emissions abatement represents an ideal opportunity to fund these services to deliver sustainable livelihood benefits. In Caprivi, collaborative CBNRM management structures involving neighbouring communities, national parks and gazetted forests facilitated coordination of fire management at a landscape scale without costly machinery and resources. With many distinct communities, differing land tenure and uses in southern African savannas, such collaborative structures are important for establishing effective offset burning projects at landscape scales.

The challenges to implement comparable emissions abatement fire management projects in southern African savannas are summarised in Table 1 in Online Resource 1.

\section{Savanna burning in south America}

\subsection{Background to savanna burning in south America}

Savannas in South America comprise five main biome areas, and cover approximately $26.9 \mathrm{M} \mathrm{km}^{2}$, representing $8-10 \%$ of the global savanna biome, and $16 \%$ of the total area of the continent (Grace et al. 2006; Chuvieco et al. 2008). Savannas show the most fire activity of all major land cover types in South America (Dwyer et al. 2000; Di Bella et al. 2006; Chuvieco et al. 2008). (See Online Resource 2 for further details on South American savannas.)

Fire has also a deep cultural significance and forms part of the traditional practice of many indigenous peoples in South America. As part of traditional practice, fire is used for such purposes as clearing forest for cultivation and for paths, visual communication, deterring dangerous animals, to facilitate hunting and fishing, to cure illnesses, and to reduce fuel loads for the prevention of large catastrophic fires (Mistry et al. 2005; Rodríguez and Sletto 2009; McDaniel et al. 2005; FIEB 2007; Bilbao et al. 2009; Pivello 2011).

4.2 Potential for emissions abatement fire management projects in south American savannas - an example from Venezuela

In exploring the potential applicability of savanna burning as an emissions reduction strategy in South American indigenous land management contexts, we share our experience in exploring 
fire management options within the upland savannas of Gran Sabana, Canaima National Park, in the Venezuelan Guiana Shield (see Online Resource 2 for greater detail).

Canaima National Park (CNP) is a region of great value due both to its biological and cultural uniqueness, and its strategic importance, both politically and economically. Annually, there are from 1000 to 3000 wildfires in the park that burn approximately 5700-7500 ha (EDELCA 2004); $73 \%$ of these begin in savanna areas and usually reach riparian and forest margins (Ablan et al. 2005). Potentially severe impacts from these fires include: the loss of buffer capacity to withstand extreme climatic events, soil degradation, changes in the water balance, degradation of landscapes that attract tourists, increased sediment loading of watercourses, alteration of biogeochemical cycles, and loss of biodiversity (Bilbao et al. 2009, 2011).

Despite the regulatory environment, Pemón Amerindian people, traditional inhabitants of the region, use fire in their daily activities, considering their fire practice an essential part of their cultural identity (Rodríguez 2007; Rodríguez and Sletto 2009). The Pemón rely on their traditional knowledge to manage fires so as to avoid fires running out of control and causing significant impacts in forested areas. Their approach is based on repeated burns of small portions of savanna of different heights (in different stages of succession), which act as natural firebreaks when fires reach the border of a previous fire. The traditional Pemón approach is thus to fight fire with fire (FIEB 2007; Bilbao personal observation). In contrast, fire fighters conventionally use water and beaters (Rodríguez 2007). The conservation policies undertaken in the past few decades in CNP based on the exclusion of fire, largely ignore the perceptions, expectations, and knowledge of the park's Pemón inhabitants, and have led to serious conflict between the Pemón people and government agencies.

The high incidence of fires in CNP and their detrimental effects on the area's ecosystems suggested that stakeholders might benefit from a change of focus from fire suppression to fire management. In considering what this would mean, a long-term experiment simulating traditional methods of fire management by the Pemón was initiated in 1999 along an experimental savanna-to-forest transect. This ecological experiment generated long-term research results of fire behaviour and its impact on the atmosphere, vegetation and soils of CNP. (See Online Resource 2 for methodology and more details of results.)

The lessons from this experiment could be directly applied within park management. In particular, the results indicated that application of a patch mosaic burning system, in which recently burned patches of savanna would serve as firebreaks, would reduce the risk of hazardous wildfires, especially in the vulnerable and diverse savanna-forest transitions (Bilbao et al. 2010). This system closely resembles the ancestral fire management practices used by the Pemón for centuries (Rodríguez and Sletto 2009). Our scientific knowledge supports the ecological wisdom of Pemón traditional knowledge and opens up possibilities for fire management based on patch mosaic burning in Canaima National Park.

\subsection{Challenges for emissions abatement fire management projects in south American} savannas

Although the initiatives for participatory management of fire in Venezuela are newer and less developed than those in Namibia and Australia, we consider that there is significant potential to further explore emissions reduction savanna fire management opportunities. Certainly, the management strategies that would work to manage fire in Venezuela have much in common with those applied in Australia. As in the case of Australia and Namibia, challenges associated with implementing such projects are apparent, some unique to South America (see Table 2 in Online Resource 1). 
Already, some actions have taken place to begin to overcome these challenges, as part of the framework of a project titled "Risk Factors in the reduction of habitats in Canaima National Park: vulnerability and tools for sustainable development". A dialogue was facilitated, in which the scientific community, resource managers and the Pemón were encouraged to reflect on their different perceptions of risk and environmental change (SánchezRose et al. in prep.). One of the results of these efforts was a greater receptiveness by the Pemón towards the exchange of their ideas and knowledge with others, when they realised that the fire experiments being carried out by the research team validated rather than questioned their fire management practices. Among the representatives of the environmental agencies we observed indications of increasing openness to other approaches, with greater recognition and respect for Pemón knowledge and recognition of the need for more participatory management. The project also resulted in formal agreements of cooperation between some relevant agencies including EDELCA (the regional hydro-electric company), INPARQUES and the Ministry of Science and Technology.

Overall, these activities are indicative of the sort of investment in stakeholder engagement and consultation that may be needed in countries such as Venezuela (Bilbao et al. 2010), and, indeed, throughout other parts of South America (Mistry et al 2011; Pivello 2011), where strategies of fire suppression and exclusion are key issues addressed in fire management policies (Julio-Alvear 2004). The implementation of community-based savanna fire management is necessary, whether that be as part of an offsets model, another kind of payment for environmental services (PES) opportunity, or simply towards joint management of fire by protected area authorities in collaboration with local indigenous communities.

Recently, the Venezuelan Ministry for Science and Technology and Innovation (FONACIT) approved a second project titled "Fire ecology and Pemón traditional knowledge: Local solutions for global problems of climate change". This project aims to build from the ecological basis of ancestral Pemón fire knowledge to develop tools to support participatory, intercultural management of fire in Canaima National Park. The project will directly involve community researchers from Pemón Arekuna people, students and academic scholars, and resource managers (EDELCA and INPARQUES). By linking research with the traditional knowledge systems of communities, as well as with technical and management agencies, the project is expected to facilitate a parks management policy that better values the contribution of Pemón knowledge to ecologically appropriate fire management, with the ultimate expectation of reducing conflict over fire in the park. Further, the project is expected to support adaptation and mitigation of climate change in a region in which climate change is expected to be leading to increasing droughts that promote greater fire intensity and extent (Martelo, 2004; IPCC 2007).

\section{Discussion}

\subsection{Applicability and benefits of emissions abatement savanna fire management}

The examples from Australia, Namibia and Venezuela suggest that emissions abatement savanna fire management is an approach that may have potentially broader application across the fire prone savanna regions of the world. Savanna management through fire is not only a possibility, but an effective environmental management tool. Savanna fire management has been shown to have the potential to contribute to a range of positive environmental outcomes, including biodiversity conservation, and in so doing has the potential to enhance the capacity of savannas to support the sustainable livelihoods of savanna based peoples (Russell-Smith et al. 2009b). Indeed, and as the case studies and cited literature describe, knowledge of fire and its 
uses has traditionally informed the management practices employed by indigenous and local communities living within these landscapes.

At the same time as mitigating climate change, supporting climate adaptation, and enhancing biodiversity conservation, the case studies demonstrate that emissions abatement savanna fire management approaches that are community-led and implemented have the potential to generate social, economic and other benefits for local communities in these settings. Given the low socio-economic status and significant needs of indigenous and local communities in the regions described, this is an important feature of the approach. (Table 3 in Online Resource 2 summarises the potential applicability of emissions abatement savanna fire management in each region, alongside a description of feasible emissions reductions, biodiversity and livelihoods benefits of the approach.)

\subsection{Implementation challenges}

Although we consider that the emissions accounting methodology developed for northern Australia has general application in other tropical savanna regions, we note that substantial further work may be required to (a) access or develop reliable seasonal fire, and vegetation/fuel type, mapping surfaces, (b) calibrate or determine appropriate parameter (e.g. fuel accumulation and combustion; emission factors for $\mathrm{CH}_{4}$ and $\mathrm{N}_{2} \mathrm{O}$ ) estimates for regional conditions, (c) help develop technical capacity (remote sensing; Geographic Information System - GIS) and associated infrastructure. Particular methodological challenges are to ensure that the application is supportive of local cultural practices and requirements, and that mitigating early dry season fire management activities actually reduce emissions - i.e. are conducted when fuels are fully cured rather than still being moist which would result in higher $\mathrm{CH}_{4}$ emissions (Meyer et al. 2012). A first step therefore is to work with local communities to assess the applicability of, and where practicable appropriately modify, the model.

While the actual operation of burning activities can be quite simple, the associated legislative, political and governance issues are often significantly more complex. In each of the case study countries complex implementation challenges are apparent (e.g. Tables 1 and 2 in Online Resource 1). Some of these challenges are common across the regions described, while others reflect the unique circumstances of the country or region in question. Many of these implementation challenges appear to have much in common with some of those encountered in the implementation of PES approaches more broadly, not least those emerging in implementation of REDD+ approaches, and discussion around topics such as REDD+ safeguards (Angelsen et al. 2012). Many of these challenges reflect the difficulties of multi-level governance - in this context international, regional and local governance systems must link and be mutually supportive for goals to be achieved at any of those levels. As international experience with PES grows, including through the many pilot projects being implemented in the area of REDD+, it is anticipated that many applicable lessons will be shared and, in particular, that promising governance models will increasingly be identified.

Particular implementation challenges for emissions abatement savanna fire management include, but are not limited to, legal and policy issues, equity and rights concerns, governance, capacity, and research needs (Table 1).

\subsection{Encouraging investment in community based savanna fire management}

Implementation challenges aside, a critical question in exploring the real opportunity for savanna fire management to contribute to emissions reductions and sustainable livelihood opportunities is whether the necessary investments to establish emissions abatement savanna 


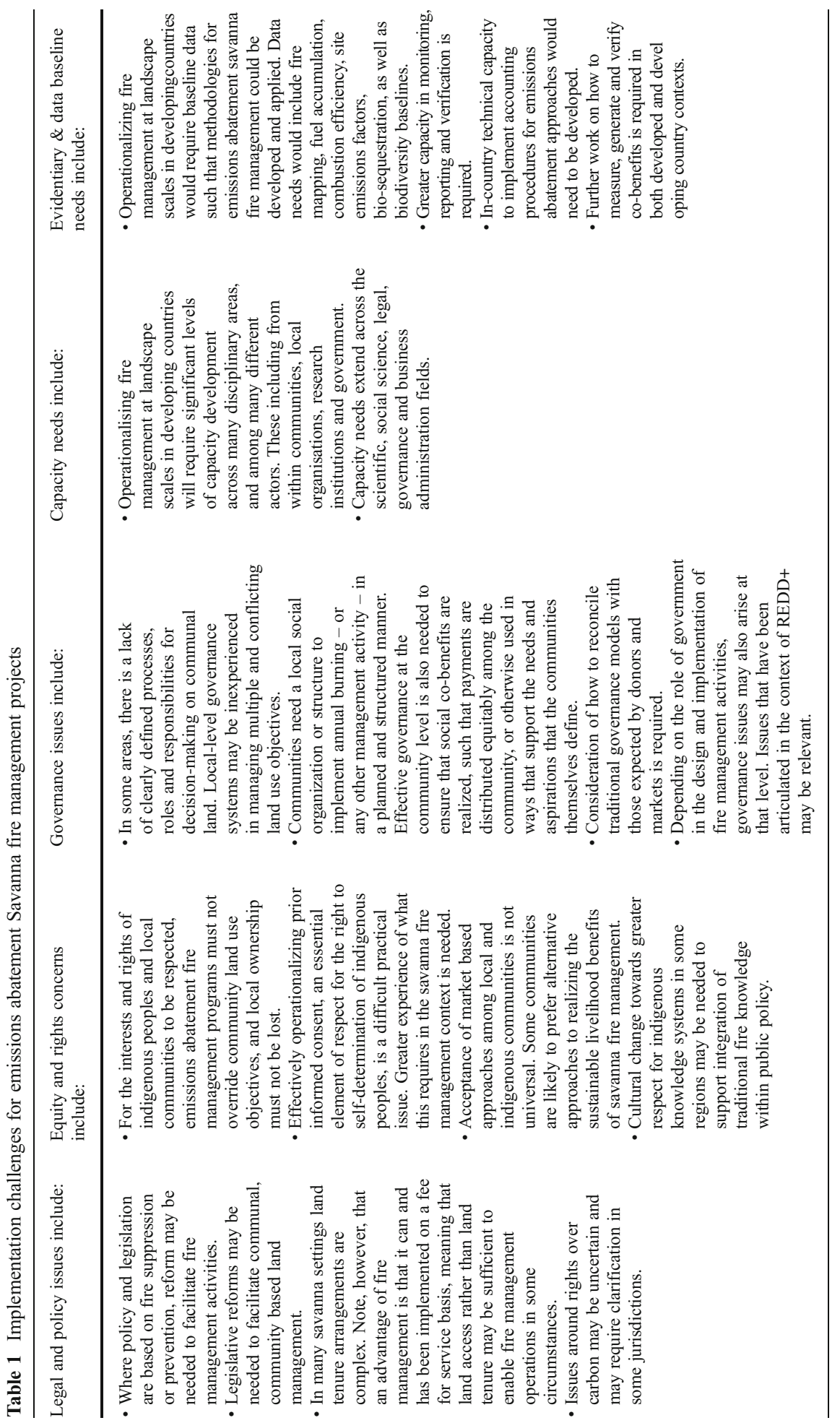


fire management will be forthcoming, and the forms that they may take. Given the diverse political, economic, and geographic contexts in which fire prone savannas exist, a range of options to encourage initial investment in, and ongoing support for, savanna fire management may be needed for the full potential of the approach for supporting sustainable livelihoods to be realized.

As described in the Australian example, an approach based on the establishment of community enterprises for generation of carbon offsets for trading in regulatory and voluntary carbon markets is being pursued, alongside direct funding of savanna fire management by the private sector as part of its corporate social responsibility agenda. Public support for infrastructure and land management activities has also effectively subsidized certain Australian savanna fire management operations (Altman and Kerins 2012). Public and private sector funding has and will continue to be essential in supporting communitybased activities and enterprises to the point that they are self-sustaining.

Such an offsets-focused, enterprise development approach looks also to have strong potential in the southern African context, assuming that implementation challenges can be overcome, and that methodological and economic feasibility is demonstrated in particular local circumstances. In South America, ongoing political discussions around the appropriate role of offset mechanisms, such as arising in the context of REDD+, may suggest that alternative approaches to incentivising emissions abatement community savanna fire management are likely to be most acceptable in the short term (UNFCCC 2012).

Where offsets projects of the kind developed in Australia would be feasible in developing countries, there is still much work to be done towards ensuring that these offsets could be effectively traded in carbon markets. As an initial step, it would be necessary to explore the feasibility of developing savanna fire management methodologies under international mechanisms such as the Kyoto Protocol's Clean Development Mechanism (CDM), under various national and regional emissions trading systems, and under voluntary carbon standards. With such methodologies and accreditations in place, offsets generated through savanna fire management in developing countries would have the potential to be traded within regulatory and voluntary carbon markets, depending on the rules and quotas associated with the scheme or schemes in question. ${ }^{2}$ Note also that in the case of many voluntary standards, projects could be tagged with additional participating co-benefits standards. These would provide recognition for the social and environmental benefits of savanna fire management that go beyond carbon abatement (VCS 2012), potentially generating price advantages for tagged offsets.

Importantly, not all areas of the world in which savanna fire management would create meaningful benefits for indigenous and local communities are likely to be as suited as the case study regions to an approach based on the establishment of economically viable community offsets enterprises. In particular, areas within fire prone savanna landscapes that are densely populated, highly fragmented, and smaller overall, such as some of the smaller savanna regions of Asia, may not be as suited to supporting viable offsets enterprises as those in areas with lower population densities and larger tracts of savanna. In such situations however, we would still argue that, while the direct financial benefits attributable to emissions reduction through savanna burning may be relatively small, encouraging more sustainable forms of savanna fire management (including support for tried and tested local knowledge systems) can contribute substantially to enhanced livelihood opportunities - for

\footnotetext{
${ }^{2}$ In the case of the Australian scheme, for example, and following the decision to link it with the European Emissions Trading System, Australian liable entities will be able to meet $12.5 \%$ of their liabilities with Kyoto units (European Commission 2012).
} 
example, in helping rehabilitate catchment management processes and productivity (Djoeroemana et al. 2007).

Although commonly thought of as applying only to denser tropical forests, REDD+ as a vehicle for encouraging investment in savanna fire management activities is also worthy of further consideration. While fire management as a stand-alone annual emissions reductions activity is not an easy conceptual fit within REDD+ given technical issues such as those around permanence (Angelsen et al. 2012), depending on the nature and scope of any mechanism or fund-based support for REDD+, savanna fire management may ultimately contribute to broader strategies aimed at preventing further deforestation and degradation, so contributing to REDD+ objectives for the conservation and the enhancement of forest carbon stocks in developing countries.

One broad limitation to the applicability of REDD+ in savannas concerns how forests are defined - while some savanna landscapes, particularly savanna woodlands, would be considered forests within applicable definitions, other areas of savanna may not (UNFCCC 2005). Despite this limitation, substantial tracts of savanna in developing countries in Asia, Africa and South America are likely to be considered forests for the purpose of REDD+, and are subject to rates of deforestation and degradation of the kind that REDD+ is intended to ameliorate (Bond et al. 2010).

\subsection{Conclusion}

Community-based, emissions abatement savanna fire management represents an opportunity for savanna based communities that is likely to be applicable across many fire prone savanna landscapes of southern Africa, South America, Asia and Australia. The cases described show savanna fire management to be an approach in which modern science and traditional practice can work together to make a measurable and significant contribution to global emissions reductions and other global sustainability goals, while contributing to building strong, sustainable livelihoods. Realizing these benefits will require investments in a range of areas, including tools that address implementation challenges, methodologies to support the engagement of developing countries in carbon markets, and the establishment of pilot initiatives to further demonstrate the value and applicability of the approach in a range of savanna settings.

Acknowledgements The United Nations University-Institute of Advanced Studies (UNU-IAS) is thanked for providing the initial venue and impetus for instigating this geographically comparative study. For the nearAustralian region, some of those ideas were explored further in a workshop co-funded by UNU-IAS and the Australian Centre for Ecological Analysis \& Synthesis (ACEAS), a facility of Australia's Terrestrial Ecosystems Research Network (TERN).

Open Access This article is distributed under the terms of the Creative Commons Attribution License which permits any use, distribution, and reproduction in any medium, provided the original author(s) and the source are credited.

\section{References}

Ablan M, Dávila M, Hoeger H, Ramos A, Rivas E, Zerpa F (2005) Modelling Fire Risk: The Upper Caroni Watershed Case. Proceedings of the VI ASTED International Conference on. Modelling, Simulation and Optimization

Altman J, Kerins S (eds) (2012) People on country: Vital landscapes, Indigenous futures. The Federation Press, Sydney

ANGA (Australian National Greenhouse Accounts) (2011) National inventory report 2009, vol 1. Dept Climate Change \& Energy Efficiency, Canberra

Angelsen A, Brockhaus M, Sunderlin WD, Verchot LV (eds) (2012) Analysing REDD+: Challenges and choices. CIFOR, Bogor 
Archibald S, Scholes R, Roy D, Roberts G, Boschetti L (2010) Southern African fire regimes as revealed by remote sensing. International Journal of Wildland Fire 2010(19):861-878

Bilbao B, Leal A, Méndez C, Delgado M (2009) The role of fire in vegetation dynamics of upland savannas of the Venezuelan Guayana. In: Cochrane MA (ed) Tropical fire ecology: Climatic change, land use and ecosystem dynamics. Springer-Praxis, Germany, pp 451-477

Bilbao B, Leal A, Méndez C (2010) Indigenous use of fire and forest loss in Canaima National Park, Venezuela. Assessment and tools for alternative strategies of fire management in Pemón indigenous land. Human Ecology 38:663-673

Bilbao B, Leal A, Mendez C, Osío A, Hasmy Z (2011) Significado ecológico de las sabanas y zonas de transición sabana — bosque en el mosaico de vegetación de la Gran Sabana, Parque Nacional Canaima. In: Herrera F, Herrera I (eds) "Experiencias de restauración ecológica en Venezuela en las últimas decadas", IVIC. Caracas, Venezuela

Bond I, Chambwera M, Jones B, Chundama M, Nhantumbo I (2010) REDD+ in dryland forests: issues and prospects for pro-poor REDD in the miombo woodlands of southern Africa, Natural Resource Issues No. 21. IIED, London

Chuvieco E, Opazo S, Sione W, del Valle H, Anaya J, Di Bella C, Cruz I, Manzo L, López G, Mari N, GonzálezAlonso F, Morelli F, Setzer A, Csiszar I, Ander Kanpandegi J, Bastarrika A, Libonati R (2008) Global burnedland estimation in Latin America using MODIS composite data. Ecological Applications 18:64-79

Cook GD, Meyer CP (2009) Fire, fuels and greenhouse gases. In: Russell-Smith J, Whitehead PJ, Cooke PM (eds) Culture, ecology and economy of savanna fire management in northern Australia: rekindling the wurrk tradition. CSIRO Publications, Melbourne, pp 313-327

DCCEE (Department of Climate Change \& Energy Efficiency) (2012) Carbon Farming (Reduction of Greenhouse Gas Emissions through Early Dry Season Savanna Burning) Methodology Determination. Canberra: DCCEE, Australian Govt. http://www.comlaw.gov.au/Details/F2012L01499. Accessed Sept 2013

de Koning F, Aguiñaga M, Bravo M, Chiu M, Lascano M, Lozada T, Suarez L (2011) Bridging the gap between forest conservation and poverty alleviation: the Ecuadorian Socio Bosque program. Environmental Science and Policy 14:531-542

Di Bella CM, Jobbágy EG, Paruelo JM, Pinnock S (2006) Continental fire density patterns in South America. Global Ecology and Biogeography 15:192-199

Djoeroemana S, Myers BA, Russell-Smith J, et al. (eds) (2007) Integrated rural development in Eastern Indonesia. ACIAR Proceedings No. 126. Australian Centre for International Agricultural Research, Canberra

Dwyer E, Pinnock S, Gregoire JM, Pereira JMC (2000) Global spatial and temporal distribution of vegetation fire as determined from satellite observations. International Journal of Remote Sensing 21:1289-1302

EDELCA (2004) La Cuenca del río Caroní. Una visión en cifras. CVG-EDELCA, Puerto Ordaz

Engel S, Palmer C (2008) Payments for environmental services as an alternative to logging under weak property rights: the case of Indonesia. Ecological Economics 65:799-809

European Commission, Australian Minister for Climate Change (2012) Linking of the European Union Emissions Trading System and the Australian Emissions Trading Scheme. Joint Press Release Ref. IP/ 12/916. Issued Brussels 28/8/12

FAO (2006) Fire management - global assessment 2006. FAO Forestry Paper 151, Rome: pp 35-42

FAO (2011) Community-based fire management in Namibia - The caprivi region integrated fire management programme. Community-based fire management - a review. FAO Forestry Paper 166, Rome: Annex 1 pp 41-47

Felderhof L, Gillieson D (2006) Comparison of fire patterns and fire frequency in two tropical savanna biomes. Austral Ecology 31:736-746

FIEB (Federacion Indígena del Estado Bolívar) (2007) Perspectivas institucionales, ecológicas y socioculturales de los incendios en el Parque Nacional Canaima: I. El fuego en la actividad económica Pemón. In: Señaris JC, Rojas H, Lew L (editors). Proceedings VII Congreso Venezolano de Ecología, La Sociedad es parte del Ecosistema. November 5-9 2007. Sociedad Venezolana de Ecología, Ciudad Guayana, pp 144-154

Frost PGH (1998) Fire in Southern African Woodlands: Origins, Impacts, Effects and Control. Meeting on Public Policies Affecting Forest Fires: FAO Forestry Paper 138, Rome: pp 181-207

Grace J, San Jose J, Meir P, Miranda HS, Montes RA (2006) Productivity and carbon fluxes of tropical savannas. J Biogeogr 33:387-400

IPCC (Intergovernmental Panel on Climate Change) (1997) Revised 1996 Intergovernmental Panel on Climate Change (IPCC) guidelines for national greenhouse gas inventories. 3 vols. IPCC/OECD/IEA, Paris

IPCC (2007). Fourth assessment report of workgroup 1. Available at www.ipcc.org. Accessed 10 Nov 2012

Jamali H, Livesley SJ, Grover SP et al (2011) The importance of termites to the CH4 balance of a tropical savanna woodland of northern Australia. Ecosystems 14:698-709

Julio-Alvear G (2004) Gestión en la Protección contra los Incendios Forestales en América del Sur. Proceedings Segundo simposio internacional sobre políticas, planificación y economía de los programs de protección contra incendios forestales: una visión global, Abril, 2004, Córdoba, España, pp 19-22 
Kamminga EM (2001) Impact of the integrated forest fire management program on rural livelihoods in East Caprivi Region, Namibia. International Forest Fire News No.25 FAO/ECE/ILO, Rome pp 39-57

Lehmann CER, Archibald SA, Hoffmann WA, Bond WJ (2011) Deciphering the distribution of the savanna biome. New Phytol 191:197-209

Martelo T (2004) Consecuencias ambientales generales del Cambio Climático en Venezuela. Primera comunicación nacional en Cambio Climatico en Venezuela. Proyecto MARN-PNUD VEN/00/G31

McDaniel J, Kennard D, Fuentes A (2005) Smokey the Tapir: traditional fire knowledge and fire prevention campaigns in Lowland Bolivia. Society and Natural Resources 18:921-931

Meyer CP, Cook GD, Reisen F et al (2012) Direct measurements of the seasonality of emission factors from savanna fires in northern Australia. J Geophys Res-Atmospheres 117, D20305. doi:10.1029/2012JD017671

Mistry J, Berardi A, Andrade V, Kraho T, Phocrok K, Leonardos O (2005) Indigenous fire management in the Cerrado of Brazil: the case of the Kraho of Tocantıns. Human Ecology 33:365-385. doi:10.1007/s10745-005-4143-8

Mistry J, Berardi A, Roopsind I, Davis O, Haynes L, Davis O, Simpson M (2011) Capacity building for adaptive management: a problem-based learning approach. Development in Practice 21:190-204

NACSO (Namibian Community-Based Natural Resource Management Support Organisations) (2012), see http://www.nacso.org.na/index accessed 20 November 2012

Pivello VR (2011) The use of fire in the Cerrado and Amazonian rainforests of Brazil: past and present. Fire Ecology 7:24-39

Rodríguez I (2007) Pemón perspectives of fire management in Canaima National Park, Southeastern Venezuela. Human Ecology 35:331-343

Rodríguez I, Sletto B (2009) Apök hace feliz a Patá. Desafíos y sugerencias para una gestión intercultural del fuego en la Gran Sabana. Antropológica, Tomo LIII (111-112): 149-191

Russell-Smith J, Yates CP, Whitehead P et al (2007) Bushfires 'down under': patterns and implications of Australian landscape burning. Int J Wildland Fire 16:361-377

Russell-Smith J, Murphy BP, Meyer CP et al (2009a) Improving estimates of savanna burning emissions for greenhouse accounting in northern Australia: limitations, challenges, applications. Int J Wildland Fire 18:1-18

Russell-Smith J, Whitehead PJ, Cooke PM (eds) (2009b) Culture, ecology and economy of savanna fire management in northern Australia: rekindling the Wurrk tradition. CSIRO Publications, Melbourne

Russell-Smith J, Cook GD, Cooke PM, et al. (2013) Managing fire regimes in north Australian savannas: applying customary Aboriginal approaches to contemporary global problems. Frontiers in Ecology and the Environment 11:e55-e63. doi:10.1890/120251

Schultz MG, Heil A, Hoelzemann JJ et al (2008) Global wildland fire emissions from 1960 to 2000. Global Biogeochem Cycles 22, GB2002. doi:10.1029/2007GB003031

UNFCCC (2005) Decision 16/CMP.1 Land use, land-use change and forestry (FCCC/KP/CMP/2005/8/Add.3)

UNFCCC (2012) Presentation of H. E. Ambassador André Correa do Lago at the Workshop on financing options for the full implementation of results-based actions relating to REDD-plus, including modalities and procedures for financing these results-based actions. Bangkok, 30 August 2012 (AWG-LCA 15 - informal)

van der Werf GR, Randerson JT, Giglio L et al (2010) Global fire emissions and the contribution of deforestation, Savanna, forest, agricultural, and peat fires (1997-2009). Atmos Chem Phys 10:11707-11735

Verified Carbon Standard (2012) Co-benefits and linking. http://v-c-s.org/co-benefits_and_linking. Accessed 7 Nov 2012

White R, Murray S, Rohweden M (2000) Pilot analysis of global ecosystems: grassland ecosystems. World Resources Institute, Washington DC 